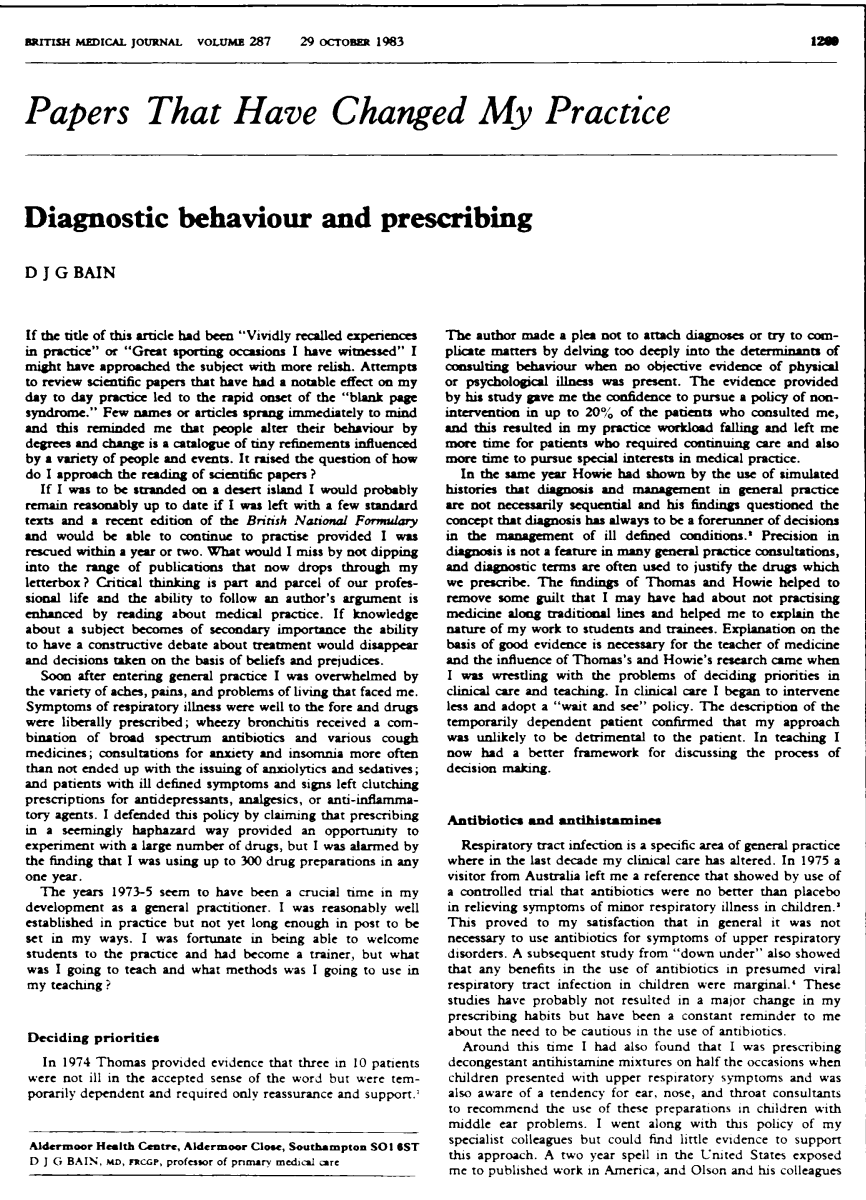

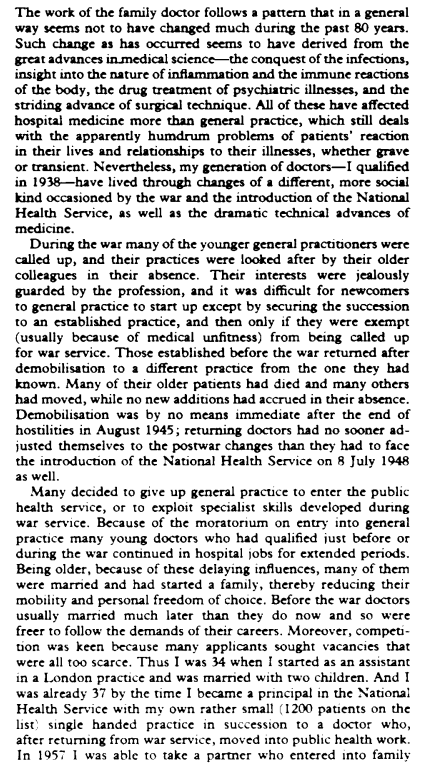

Combe Lene Cottage, Wormley, Surrey GU8 $5 T A$
JOHN HEWETSON, Ma, MRCCF, general practitioner entited to free doctoring, free medicines, and sickness bene-h
when they were of work through illiness. This meant that most
men and most unmarried worting women had access to free We were much: more poverty conscious in those days. In-
ostigations on hospitals its effects were in some respects the reverse. Befortine
1948 consultants in the teaching hospotals were not paid; the

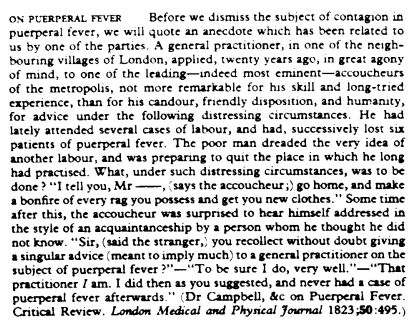

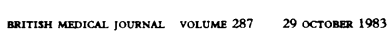

First Five Years in Practice: the 1940s

\section{Before and after the "appointed day"}

JOHN HEWETSON

practice at the age of 26 . All my parterers since then, with the
exception of ofe who came to us aster several years in hospital

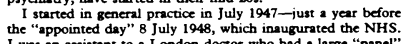
I was an assiscant to a London doctor who had a large "Nanel." to look after the panel patients, doing the cwice dealy surgeries
and the visits, night calls, and the weeckends; we wednesddy affer-
noon was my haif day. Assistants were modesty paid, and assisnoon was my haif day. Assistants were modestly paid, and asci-
tanships were hard to get; I was considerably overworted but gained an immense amount of experience.
Many people, including some doctors, seem to think that there Many people, including some doctors, seem to think that there
was no such thing as a free medical service before the NHS
come in. If this were 30 , 8 July 1948 would have caused an immense upheaval. In fact, the change from the old National
Health Insurance scarcely altered the daily partern of general practice. The National Health Insurance Act was conceived by
Lloyd George in 1909 and came into effect in 1911 . To my father's generation of doctors it must have seemed far more
revolutionary than its successor of 1948 did to us. The National Health Insurance Act required all employees whose carnings
werc below a certain figure and their employers to pay a weectly were below a certain figure and their employers
sum (in the form of special stamps) to one of the insurance companies that were "approved" under the Act-such as the Pruden-
rial and the Liverpool Victoria, whose tial and the Liverpool Victoria, whose names are still to be found
on the notes of elderly patients. Those insured were thereby men and most unmarried working women had access to free
treatment. Married women who did not go out to 2 job and
hhildren were not covered, and they had to pay their doctor. traiment. Wre not covered, and they had to pay their doctor.
childen fees, however, were not burdensome-about one shilling

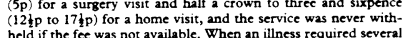
held if the fee was not available. When an illness required several
repeat visits, and so might have caused hardship, one could repeat visits, and so might have caused hardship, one could
preetend that one "just dropped in because one happened to be
passing "Pats passing." "Patients sometimes, however, saw through these ruses
and didn't like them: "Oh, come on, doctor, we're not that poor." vestigations on diets berween the wars, especially the work of Sir
John Boyd Orr (Food, Health and Income), had made us aware how widespread and morbidity rates of poorer people. In the casualty outpatient departments in the late 1930 we used to prescribe a lot
of cod liver oil and malt, nominally as medicine, but actually as of cod liver oil and malt, nominally as medicine, bur actually as
food to the very poorest. With the NHS married women and children came into free medical care, and all the discomforts of
charging went by the board, to our great relief. But these patients who then came on to our panel lists were already welli known to us
because we were then, as now, family doctors. It was only the
fee paying that changed-and all the tiresome logging them up fee paying that changed-and all the tiresome logging them up
which was necessary for accounting purposes. The NHS also
brought in salaried people and their wives-peopie whose

1272 income was above the National Health Insurance celling. Many
howevere, chose to remain as private patients at firts. In the
practice in which I worked we had tomo patients on the list, and

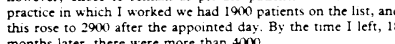
Coofficial training

In those days there was no officiai training for general practice. but the casualty outpanent departments before 1948 were
good unofficial training ground. Casualty officers dealt with fractures and accidents and also had long surgeries sometimes
going on into the afternoon) in which women and children going on into the afternoon in which women and children
considerably outrumbered men. Casualty yoficers got to know
their patients well, just as family doctors do, especially if the appointments were prolonged. They dealt with the lamila
ailments of gencral practice, and thetr patients were manly
those who were not insured with the National Health Insuran

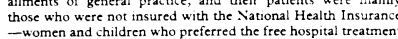

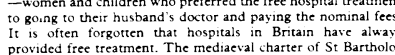

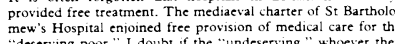

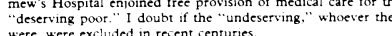
were, were excluded in recent centurles.
Lloyd George's Act was revolutionary because it provided

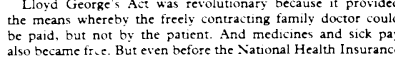

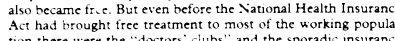

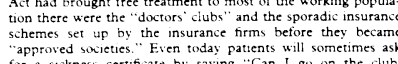

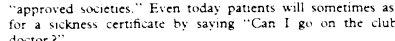

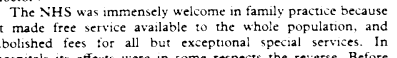
were honorary consultants. In the municipal hospitals they werc
salaried and usually excluded from private practice. It was expected that an honorars consultant would give hils hospita
patients exactly the same care and expertise as he gave to $h$. private patients, and tradition ensured that he did. 1 knew
surgeon who all too frequently left his hospital outpatien surgeon who all too frequently left his hospital outpatien
sessions to hos registrat The hospital management commitre
reminded him rather pointedty that his appointment was reminded hims rather pointedly that his appointment uas
enewabic annually.

BRITISH MEDICAL JOLRNAL VOLLME $287 \quad 29$ OCTOBER 1983 waiting lists were virtually unknown. After 1948 consultants
were paid on a sessional basis, and this required that a session
be defined; no more than so many patients, of what than so many must be new patients. For many of the older consultants this shangeover must have been strange and a
limitation. Undert the "honorary" system waiting lists did not Pressure on the hospitals has increased enormously and has led to another form of restrictuve practice, the concept of
atchment arca. Brought in originally to deal with emergencies,

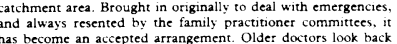
a dith nostalgia to the days when they could refer their patients
with are enionied to porovede che elest treatment for their patient in
he family doctor's terms of service. Pressure on consultants has in some areas been relaxed,
huever. When I was first in practice investigations except

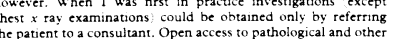
investigations to family doctors must have relieved consultants
of a great deal of work, and it is now difficult to remember
what general practice was like without access to services that hat general practice was like without access to services that
oday are regarded as essential. The NHS rook over from the National Health Insurance
unchanged the way in which family doctors were paid. This
was by a "capitation" fee for every patient on his list. This

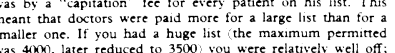
whic a doctor with a small list had more time to spend on his
white patients, but was paid less for so doing. Furthermore, alf
parctice expenses, such as rent, equipment, and ancillary help,
had to comne out of the total of captation fees. There was a nancial incentive to spend as litrie as possible, indeed to do as
ctile as possible for your patients. Looking back, it seems to way that they looked after their patients under this system of
payment. It may be that the change in this system under what nost important factor in making it possible for general practitioners to provide the different, and much improved, service
that they give today. But it is also true that the atritude of most octors to their patients was of a high order under the National
Health Insurance Act, the early days of the $\mathrm{NHS}$, and these terter years during which general practice has undergone a Beveridge, of Lloyd George, and of the great social reformers
of the nineteenth century, like Lord Shaftesbury, could hardly have been transiated into present day reality without this
tradition of doctors themselves

Diary of Urban Marks: 1880-1949

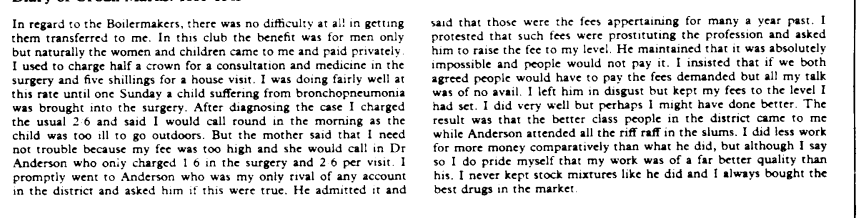

